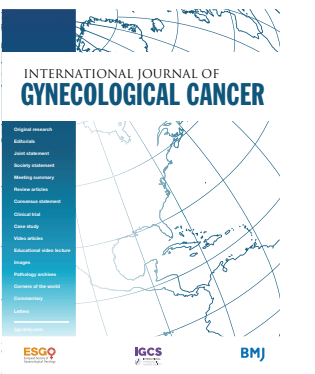

${ }^{1}$ Department of Metabolism, Digestion, and Reproduction, Imperial College London, London, UK

${ }^{2}$ Department of Surgery and Cancer, Imperial College London, London, UK ${ }^{3}$ Department of Pathology, Faculty of Medicine, University of Alexandria, Alexandria, Egypt

Correspondence to Professor Mona El-Bahrawy, Metabolism, Digestion, and Reproduction, Imperial College London Faculty of Medicine, London, W12 ONN, UK; m. elbahrawy@imperial.ac.uk

Received 7 September 2020 Revised 24 November 2020 Accepted 30 November 2020 Published Online First 7 January 2021

\section{SLinked}

- http://dx.doi.org/10.1136/ ijgc-2020-002329

Check for updates

(C) IGCS and ESGO 2021. No commercial re-use. See rights and permissions. Published by BMJ.

To cite: Al Harbi R, McNeish IA, El-Bahrawy M. Int J Gynecol Cancer 2021;31:161-168

\title{
Ovarian sex cord-stromal tumors: an update on clinical features, molecular changes, and management
}

Rehab Al Harbi, ${ }^{1}$ Iain A McNeish, ${ }^{2}$ Mona El-Bahrawy ${ }^{1,3}$

\begin{abstract}
Sex cord stromal-tumors are rare tumors of the ovary that include numerous tumor subtypes of variable histological features and biological behavior. Surgery is the main therapeutic modality for the management of these tumors, while chemotherapy and hormonal therapy may be used in some patients with progressive and recurrent tumors. Several studies investigated molecular changes in the different tumor types. Understanding molecular changes underlying the development and progression of sex cord-stromal tumors provides valuable information for diagnostic and prognostic biomarkers and potential therapeutic targets for these tumors. In this review, we provide an update on the clinical presentation, molecular changes, and management of sex cord-stromal tumors.
\end{abstract}

\section{INTRODUCTION}

Sex cord-stromal tumors are rare tumors of the ovary that usually occur in the first two to three decades of life ${ }^{12}$ and represent approximately $7 \%$ of all primary malignant ovarian tumors, ${ }^{3}$ with the exception of adult granulosa cell tumors, which are characterized by later onset with a peak incidence between 50 and 55 years of age. ${ }^{1}$ Sex cord-stromal tumors are usually diagnosed at an early stage, and may have late recurrence, as late as 30 years, after the initial diagnosis and treatment. ${ }^{4}$ The longest period of recurrence of granulosa cell tumors after initial diagnosis reported was 41 years. ${ }^{5}$ Sex cord-stromal tumors constitute a heterogeneous group of benign and malignant neoplasms and are formed by distinct cell types that arise from stromal cells or primitive sex cord cells. ${ }^{67}$

\section{CLASSIFICATION OF SEX CORD-STROMAL TUMORS}

These tumors are classified into three main groups, according to the World Health Organization, as presented in Table 1, and include pure stromal tumors, pure sex cord tumors, and mixed sex cordstromal tumors. ${ }^{7}$ Pure stromal tumors arise from mesenchymal cells of the ovarian stroma, and include fibromas, thecomas, sclerosing stromal tumors, microcystic stromal tumors, Leydig cell tumors, and steroid cell tumors. ${ }^{7}$ Pure sex cord tumors, such as granulosa cell tumors, Sertoli cell tumors, and sex cord tumors with annular tubules, arise from primitive sex cord cells. ${ }^{7}$ Mixed sex cord-stromal tumors include Sertoli-Leydig cell tumors and sex cordstromal tumors that have not otherwise been specified. $^{7}$

Sex cord-stromal tumors may present with an adnexal mass, abdominal distention, and abdominal pain. ${ }^{1}$ Unlike epithelial and germ cell tumors, some sex cord-stromal tumors have clinical signs of hormone production, including menstrual changes, precocious puberty, hirsutism, and/or virilization. ${ }^{1}$ The most important prognostic factors for sex cordstromal tumors are the International Federation of Gynecology and Obstetrics (FIGO) stage and tumor rupture. $^{4}$

\section{PURE STROMAL TUMORS}

\section{Fibromas}

Fibromas are relatively common tumors and account for $4 \%$ of all ovarian tumors. ${ }^{8}$ These solid, typically benign, tumors arise from spindle shaped stromal cells that form collagen. ${ }^{9}$ These hormonally inactive tumors occur most often in perimenopausal and postmenopausal women. ${ }^{9}$ Fibromas are commonly unilateral; however, bilateral cases may occur and may be associated with Gorlin syndrome. ${ }^{10}$ Gorlin syndrome, also called nevoid basal cell carcinoma syndrome or basal cell nevus syndrome, is a rare hereditary disease and it is inherited in an autosomal dominant manner. ${ }^{11}$ It affects multiple organ systems of the human body and is associated with an increased risk of developing several types of benign and malignant tumors. ${ }^{11}$ This syndrome is caused by a germline mutation in the human homolog of the patched (PTCH1) gene, which is located on chromosome $9 .{ }^{12}{ }^{13}$ However, It is still unclear whether this germline mutation is also involved in the development of sporadic ovarian fibromas. ${ }^{14}$ Molecular cytogenetics analysis by fluorescence in situ hybridization has shown the presence of trisomy 12 in fibromas. ${ }^{15}$

\section{Thecomas}

Thecomas are very rare tumors and represent approximately $0.5-1 \%$ of all ovarian tumors. ${ }^{16}$ They can occur at any age and can be seen in women 
Table 1 World Health Organization classification of ovarian sex cord-stromal tumors

\begin{tabular}{|c|c|}
\hline Tumor type & \\
\hline Pure stromal tumors & \\
\hline Fibroma & $4 \%$ of all ovarian tumors ${ }^{8}$ \\
\hline Cellular fibroma & \\
\hline Thecoma & $\begin{array}{l}0.5-1 \% \text { of all ovarian } \\
\text { tumors }^{16}\end{array}$ \\
\hline $\begin{array}{l}\text { Luteinized thecoma } \\
\text { associated with sclerosing } \\
\text { peritonitis }\end{array}$ & \\
\hline Fibrosarcoma & \\
\hline Signet ring stromal tumor & \\
\hline Sclerosing stromal tumor & $\begin{array}{l}5 \% \text { of all sex cord stromal } \\
\text { tumors }\end{array}$ \\
\hline Microcystic stromal tumor & \\
\hline Leydig cell tumor & \\
\hline Steroid cell tumor & \\
\hline $\begin{array}{l}\text { Steroid cell tumor, } \\
\text { malignant }\end{array}$ & \\
\hline Pure sex cord tumors & \\
\hline Adult granulosa cell tumor & $\begin{array}{l}95 \% \text { of all granulosa cell } \\
\text { tumors }^{68}\end{array}$ \\
\hline $\begin{array}{l}\text { Juvenile granulosa cell } \\
\text { tumor }\end{array}$ & $\begin{array}{l}5 \% \text { of all granulosa cell } \\
\text { tumors }^{68}\end{array}$ \\
\hline Sertoli cell tumor & \\
\hline $\begin{array}{l}\text { Sex cord tumors with } \\
\text { annular tubules }\end{array}$ & $\begin{array}{l}1.4 \% \text { of all sex cord-stromal } \\
\text { tumors }^{81}\end{array}$ \\
\hline Mixed sex cord stromal tumo & \\
\hline Sertoli-Leydig cell tumors & $\begin{array}{l}<0.5 \% \text { of all ovarian } \\
\text { tumors }^{84}\end{array}$ \\
\hline Well differentiated & \\
\hline Moderately differentiated & \\
\hline $\begin{array}{l}\text { With heterologous } \\
\text { elements }\end{array}$ & \\
\hline Poorly differentiated & \\
\hline $\begin{array}{l}\text { With heterologous } \\
\text { elements }\end{array}$ & \\
\hline Retiform & \\
\hline $\begin{array}{l}\text { With heterologous } \\
\text { elements }\end{array}$ & \\
\hline $\begin{array}{l}\text { Sex cord-stromal tumor, } \\
\text { not otherwise specified }\end{array}$ & \\
\hline
\end{tabular}

under 30 years of age. ${ }^{17}$ These tumors are hormonally active and consist of lipid laden stromal cells that may or may not be luteinized. Cytogenetics analysis of thecoma has identified the presence of trisomies of chromosomes 12 and $4 .{ }^{18}$ Trisomy 12 is the most frequent aberration in benign sex cord-stromal tumors, and it is suggested that trisomy 4 may be a later event in the tumorigenesis of thecoma. ${ }^{18}$

\section{Sclerosing Stromal Tumors}

Sclerosing stromal tumors represent less than approximately $5 \%$ of all sex cord-stromal tumors, ${ }^{7}$ and $70 \%$ are diagnosed in young women aged $14-29 .{ }^{19}$ These tumors are usually unilateral and hormonally inactive. However, sclerosing stromal tumors may present with hormonal manifestations, primarily androgenic ones, and they occur more frequently during pregnancy. ${ }^{20}$ On immunostaining, sclerosing stromal tumors show strong TFE3 expression, which is a transcription factor binding to the immunoglobulin heavy chain enhancer $3 .{ }^{21} \mathrm{~A}$ study using whole exome, targeted capture, and RNA sequencing identified recurrent gene fusions of FHL2-GLI2 in $65 \%$ and other GLI2 rearrangements in $15 \%$ of sclerosing stromal tumors, but none of these fusion genes has been reported in other types of sex cord-stromal tumors. ${ }^{22}$ FHL2-GL/2 fusions activate the sonic hedgehog pathway in sclerosing stromal tumors and could, therefore, serve as an oncogenic driver of sclerosing stromal tumor. ${ }^{22}$

\section{Microcystic Stromal Tumors}

Microcystic stromal tumors are very rare and present in patients between the ages of 20 and $60 .{ }^{23}$ On immunostaining, microcystic stromal tumors have shown the expression of CD10, vimentin, and Wilms tumor 1 , while sex cord-stromal markers ( $\alpha$-inhibin and calretinin) and epithelial membrane antigen are negative..$^{24}$ Nuclear expression of $\beta$-catenin occurs in microcystic stromal tumors. ${ }^{25}$ The somatic exon 3 missense CTNNB1 mutation is a hallmark of most ovarian microcystic stromal tumors. ${ }^{25}$ The CTNNB1 gene encodes the $\beta$-catenin protein, and this mutation leads to the loss of a phosphorylation site in the $\beta$-catenin protein. Also, microcystic stromal tumors may be associated with familial adenomatous polyposis, which is an autosomal dominant inherited disease caused by germline mutations of the adenomatous polyposis coli gene on chromosome 5 (q21-22) ${ }^{26}$ A case study of the molecular analysis of microcystic stromal tumors by Zhang et al identified two missense mutations, one in exon 1 of the KRAS gene and the other in exon 15 of the adenomatous polyposis coli gene. ${ }^{27}$

\section{PURE SEX CORD TUMORS}

\section{Granulosa Cell Tumors}

Granulosa cell tumors are the most common subtype of sex cordstromal tumors, accounting for $2-5 \%$ of all ovarian tumors. ${ }^{28} 29$ Granulosa cell tumors originate from normally proliferating granulosa cells of late preovulatory follicles, with which they share similar biochemical, morphological, and hormonal characteristics, including the expression of inhibin, estrogen, and Müllerian inhibiting substance. ${ }^{28} 30$ These hormones account for some of the clinical manifestations and provide valuable tumor markers for monitoring disease progression and treatment efficacy. ${ }^{28} 3031$

Inhibin is a glycoprotein hormone produced by ovarian granulosa cells and plays an essential role in the negative feedback regulation of pituitary follicle stimulating hormone secretion from the pituitary. ${ }^{32}$ Inhibin is composed of an alpha subunit and one of two beta subunits, either a beta $A$ subunit (inhibin $A$ ) or a beta $B$ subunit (inhibin B). ${ }^{334}$ Serum inhibin A and B fall to very low or even undetectable levels in postmenopausal women due to the depletion of ovarian follicles. ${ }^{35}$ In contrast, serum inhibin A and B levels rise with granulosa cell tumors. ${ }^{35}$ Therefore, inhibin can be used as a tumor 
marker for primary as well as recurrent granulosa cell tumors. ${ }^{36}$ Studies using subunit specific enzyme linked immunosorbent assay showed inhibin $B$ is the main form of inhibin produced by granulosa cell tumors and the serum inhibin B level is more effective than inhibin A level in reflecting disease status. ${ }^{35} 3738$

Estradiol is the key steroid hormone secreted by granulosa cell tumors in the presence of theca cells and it is accountable for the clinical signs of hyperestrogenism, such as precocious puberty. ${ }^{39}$ Approximately $70 \%$ of patients with granulosa cell tumor have elevated circulating levels of estradiol, ${ }^{40}$ whereas about $30 \%$ of patients with granulosa cell tumor do not produce estradiol due to the lack of theca cells in the tumor stroma. ${ }^{39}$ Therefore, although estradiol may be useful in monitoring the course of disease, it does not display a high degree of sensitivity to act as a reliable tumor marker for patients with granulosa cell tumors. ${ }^{39}$ Serum concentrations of estradiol are initially elevated in the early course of the disease, but rapidly decrease within 3 months after surgical removal of the tumor. ${ }^{41}$

This rapid decline in serum estradiol concentration is confirmed by a very low level in 24 hour urinary total estrogen excretion, decreasing from 504 to $108 \mathrm{nmol}$ per day (normal range 14-216) within the first 48 hours following surgery, ${ }^{41}$ while the urinary estradiol level drops from 385 to 73 nmol per day (normal $<250$ ). ${ }^{41}$

Mullerian inhibiting substance, also known as anti-Mullerian hormone, is a glycoprotein hormone and a member of the transforming growth factor $\beta$ family. ${ }^{42}$ In women, anti-Mullerian hormone is secreted mainly by ovarian granulosa cells of small follicles and plays an important role in the control of follicular growth. ${ }^{43} 44$ Women have undetectable serum anti-Mullerian hormone levels until the prepubertal period, whereas after puberty, serum antiMullerian hormone levels of $2-5 \mathrm{ng} / \mathrm{mL}$ remain constant until clinical menopause when the levels become undetectable. ${ }^{45}$

There are two types of granulosa cell tumors, which differ based on clinical signs and histopathological features: adult granulosa cell tumors and juvenile granulosa cell tumors. ${ }^{46}$

\section{Adult Granulosa Cell Tumors}

Adult granulosa cell tumors account for approximately $95 \%$ of all granulosa cell tumors, present in perimenopausal and postmenopausal women, with a peak incidence in women aged $50-55$. $^{47}$ Adult granulosa cell tumors are the most common malignant ovarian tumors that secrete hormones, primarily estrogen, and lead to endometrial alterations, such as hyperplasia and endometrial cancer. Patients often exhibit one or more of the following symptoms: abnormal vaginal bleeding, abdominal pain, or abdominal distension. ${ }^{48}$ These tumors are usually considered low grade malignant tumors with a tendency to remain localized and demonstrate an indolent clinical course and late relapse. ${ }^{50}$ Several studies have reported that approximately $70-97 \%$ of adult granulosa cell tumors carry a somatic $c .402 C>G$ missense point mutation in the FOXL2 gene. ${ }^{51-53}$ The FOXL2 gene encodes a transcription factor that is expressed in different tissue types, including the ovaries and pituitary gland. This gene plays an essential role in ovarian development and differentiation. This single missense mutation is a rather pathognomonic hallmark of adult granulosa cell tumors, and is rarely seen in other ovarian tumors. ${ }^{255455}$ This makes FOXL2 a highly sensitive and relatively specific marker for adult granulosa cell tumors, as well as a useful diagnostic test for distinguishing between adult and juvenile granulosa cell tumors types and other sex cord-stromal tumors. ${ }^{56}$ FOXL2 has been shown to interact directly with other genes involved in the pathogenesis of adult granulosa cell tumors, including CCND2, GATA4, and SMAD3. ${ }^{57}$ Furthermore, FOXL2 expression is a potential prognostic marker for adult granulosa cell tumors, where patients with higher FOXL2 expression have a worse prognosis and worse overall rates of disease free survival than patients with negative or weak expression. ${ }^{58}$

Several studies have investigated copy number changes in adult granulosa cell tumors and reported that gains in chromosomes 12 and 14 are observed in about $30 \%$ of adult granulosa cell tumors, while chromosome 22 loss occurs in about $40 \%$ of adult granulosa cell tumors. ${ }^{59-61}$ A molecular study using comparative genomic hybridization and transcriptomic analyses of adult granulosa cell tumors has shown the presence of highly recurrent chromosomal imbalances, such as trisomy 14 and monosomy 22, as well as preferential co-occurrences, such as trisomy 14/monosomy 22 and trisomy $7 /$ monosomy $16 q .{ }^{61}$ This study also showed copy number changes in other genes, including LIMA1, RUNX1, and AKT1. ${ }^{61}$ These alterations may be involved in adult granulosa cell tumor development and progression, along with the confirmed FOXL2 somatic mutation. ${ }^{61}$

Significant differences in gene expression have been identified between early (stage I) and advanced (stage III) adult granulosa cell tumors. Genes with the greatest fold change in expression included cytokine CXCL14 (chemokine C-X-C-motif ligand 14) and MFAP5 (microfibrillar associated protein 5 transcript variant 1). These two genes are prominently expressed in advanced stage adult granulosa cell tumors, while INSL3 (insulin-like 3 transcript variant 2) is highly expressed in stage I adult granulosa cell tumors. ${ }^{56} 62$

Another study conducted by Alexiadis et al showed that a high frequency of promoter mutations in telomerase reverse transcriptase $-124 \mathrm{C}>\mathrm{T}$ in adult granulosa cell tumors is associated with more aggressive disease progression. ${ }^{59}$ Kraus et al found that the presence of chromosome instability and FOXL2 homozygous genotypes primarily appeared to predict early recurrence and aggressive tumors. ${ }^{63}$ Furthermore, a case study of adult granulosa cell tumors performed by Wang et al revealed that a DNA replication error is detectable when analyzing lengths of cytosine-adenine-guanine (CAG) repeats in the androgen receptor gene. ${ }^{64}$ They implied that the influence of deficient DNA mismatch repair is associated with malignant behavior in adult granulosa cell tumors, and that this deficiency is an early event in tumor development and progression. ${ }^{64}$

Using methylation specific polymerase chain reaction analysis, Xu et al examined the hypermethylation of Dickkopf WNT signaling pathway inhibitor DKK3, CDH13, and FOXL2 promoters in 30 granulosa cell tumors and in follicular cyst tissue specimens used as controls. ${ }^{65}$ The results showed that the frequency of $\mathrm{CDH13}$, $D K K 3$, and FOXL2 promoter methylation was significantly higher in granulosa cell tumors compared with follicular cyst tissue. ${ }^{65}$ Furthermore, immunostaining of EZH2, a histone H3K27 methyltransferase, showed that there was no expression of the $\mathrm{EZH} 2$ protein in the 30 follicular cyst samples, while EZH2 protein was expressed in 11 of the 30 granulosa cell tumors. ${ }^{65}$ Another study of the methylation status of five gene promoters, including FHIT, FNACF, Cyclin D2, BRCA2, and RUNX3, in 25 granulosa cell tumors, showed that the methylation frequency was $28 \%$ for FHIT, $24 \%$ for FNACF, $12 \%$ for Cyclin D2, 4\% for BRCA2, and 56\% for RUNX3 


\section{Review}

genes. ${ }^{66}$ Furthermore, the correlation of clinical features with promoter methylation status showed that overall promoter methylation was higher in higher stage tumors. ${ }^{66}$ Another study performed by Dhillon et al assessed the promoter hypermethylation of different tumor suppressor genes, including MGMT, CDH1, RAR-beta, and $S Y K$ in 43 adult granulosa cell tumors. ${ }^{67}$ They observed the hypermethylation of MGMT in 32\%, CDH1 in 21\%, RAR-beta in 19\%, and SYK in $16 \%$ of tumors. ${ }^{67}$

\section{Juvenile Granulosa Cell Tumors}

The juvenile granulosa cell tumor subtype represents about $5 \%$ of all granulosa cell tumors. ${ }^{68} 69$ Juvenile granulosa cell tumors are usually found in women younger than age 30 , with a mean age of 13 years. ${ }^{70}$ Clinical presentations of juvenile granulosa cell tumors include precocious pseudopuberty, vaginal bleeding, irregular menstruation and, in rare cases, virilization or hirsutism. ${ }^{68}$ Approximately $80 \%$ of juvenile granulosa cell tumors presenting in children result in isosexual precocity. ${ }^{71}$ Generally, juvenile granulosa cell tumors have a relatively favorable prognosis and are almost always unilateral and confined to the ovary.

Unlike adult granulosa cell tumors, juvenile granulosa cell tumors have either low or absent FOXL2 protein expression, providing a clear distinction between juvenile and adult types. ${ }^{72}$ However, loss of FOXL2 expression in juvenile granulosa cell tumors may be associated with aggressive disease progression and poorer prognosis, given that the expression of FOXL2 is essential for establishing and maintaining granulosa cell identity in the adult ovary. ${ }^{73}$ Mutations in the GNAS gene, which encodes the stimulatory G protein, have been implicated in the development of juvenile granulosa cell tumors. ${ }^{72}$ GNAS mutations have not been documented in the adult type or in other ovarian tumors. ${ }^{72}$ The GSP oncogene mutation is a constitutive activating mutation of the Gs $\alpha$ subunit and has frequently been observed in approximately $30 \%$ of juvenile granulosa cell tumors. The exact role of GSP mutation in the malignant transformation of granulosa cells remains unknown, but its presence correlates with a poorer prognosis. ${ }^{74}$ A study conducted by Bessiere et al showed that more than approximately $60 \%$ of juvenile granulosa cell tumors bear in-frame duplications in the oncogene $A K T 1{ }^{75}$ Tumors without AKT1 in-frame duplications often carried two or more point mutations that altered highly conserved residues. ${ }^{75}$

\section{Sertoli Cell Tumors}

Sertoli cell tumors are rare, and are present in women of reproductive age and sometimes in children. ${ }^{76}$ Sertoli cell tumors are hormonally active in approximately $40-60 \%$ of cases; usually estrogenic but occasionally androgenic, and rarely both. ${ }^{76}$ Pejovic et al reported the presence of isochromosome 1q as the sole chromosomal abnormality in ovarian Sertoli cell tumors. ${ }^{77}$ 0ccasionally, Sertoli cell tumors of the testis occur in patients who have PeutzJeghers syndrome, ${ }^{78}$ which is an autosomal dominant hereditary syndrome caused by germline mutations in the STK11/LKB1 gene. ${ }^{79}$ The syndrome is characterized by hamartomatous gastrointestinal polyps and mucocutaneous pigmentation and a predisposition to development of tumors at different sites. ${ }^{80}$

\section{Sex Cord-Stromal Tumors with Annular Tubules}

Sex cord-stromal tumors with annular tubules represent $1.4 \%$ of all sex cord-stromal tumors and usually present at a mean age of
22.6 years. ${ }^{81}$ Sex cord-stromal tumors with annular tubules have two different clinical types: one is associated with Peutz-Jeghers syndrome and the other is sporadic. Approximately $36 \%$ of sex cord stromal-tumors with annular tubules cases are associated with Peutz-Jeghers syndrome. ${ }^{82}$ Sex cord-stromal tumors with annular tubules associated with Peutz-Jeghers syndrome are mostly benign, bilateral, or multifocal, and very small, whereas sporadic sex cord-stromal tumors with annular tubules are usually unilateral, large, and may have malignant potential. ${ }^{83}$ Somatic mutations in the SKT11 gene have not been detected in sporadic sex cordstromal tumors with annular tubules. ${ }^{82}$

\section{Mixed Sex Cord-Stromal Tumors}

Sertoli-Leydig Cell Tumors

Sertoli-Leydig cell tumors are rare, representing less than $0.5 \%$ of all ovarian tumors. ${ }^{84}$ About $75 \%$ of Sertoli-Leydig cell tumors present in women under the age of $30 .{ }^{85}$ These tumors are hormonally active, usually producing androgens, but sometimes producing estrogen. Approximately $80 \%$ of patients with ovarian Sertoli-Leydig cell tumors present with virilizing manifestations. ${ }^{86}$ Most of these tumors are unilateral and confined to the ovary, and approximately $90 \%$ of cases are diagnosed at stage I. ${ }^{86}$ SertoliLeydig cell tumors are associated with both somatic and germline DICER1 mutations, which encode an RNA endoribonuclease that cleaves microRNA precursors to generate mature microRNA ${ }^{25}$ However, tumors without DICER1 hot spot mutations exhibit no androgenic manifestations and usually present in elderly patients. ${ }^{87}$ A case study of metastasizing Sertoli-Leydig cell tumors showed the presence of trisomy 8 as the sole karyotypic abnormality in ovarian Sertoli-Leydig cell tumors. ${ }^{88} \mathrm{~A}$ molecular-cytogenetic analysis of two cases of testicular Sertoli-Leydig cell tumors and one case of ovarian Sertoli-Leydig cell tumor with benign behavior showed DNA copy number changes in entire chromosomes or chromosome regions, including $1 p, 8,9 p, 1 q, 12,16 q, 19,22$, and $X^{89}$

\section{MANAGEMENT AND PROGNOSIS OF SEX CORD-STROMAL TUMORS}

There are a variety of treatment options available, including surgery, chemotherapy, hormonal therapy, and targeted therapy. These therapies may be used either alone or in combination, depending on several factors, including age, type, and stage of the tumor. Surgery is generally considered the most effective treatment for sex cordstromal tumors. As the majority of patients diagnosed with sex cord-stromal tumors usually present with stage I disease, surgery is the treatment of choice. Total abdominal hysterectomy and bilateral salpingo-oophorectomy are appropriate for postmenopausal women. ${ }^{90}$ In contrast, a more conservative unilateral salpingooophorectomy is appropriate for women of reproductive age when the tumor is confined to one ovary. ${ }^{90}$

\section{Surgery}

As sex cord-stromal tumors tend to present generally in younger patients with early stage disease ${ }^{91}$ fertility sparing surgery (unilateral salpingo-oophorectomy with surgical staging) may be offered to young patients with early stage disease who wish to preserve fertility. ${ }^{46} 91$ Subsequent completion surgery (total abdominal hysterectomy and removal of the other ovary) is a reasonable 
consideration at an older age. ${ }^{92}$ Moreover, it is recommended to perform an endometrial biopsy for patients who choose fertility sparing surgery to rule out endometrial hyperplasia or carcinoma. ${ }^{92}$ A retrospective study of $36 \mathrm{FIGO}$ stage I adult granulosa cell tumor patients reported that $17(47 \%)$ patients presented with endometrial alterations, as atypical hyperplasia or endometrial carcinoma. ${ }^{93}$ This emphasizes the importance of endometrial assessment and endometrial biopsy during the fertility and uterine preservation procedure in order to rule out a concomitant neoplasia. ${ }^{93}$

There are no standard therapies for the management of advanced or recurrent sex cord-stromal tumors. However, secondary cytoreductive surgery is the preferred option for the management of recurrent tumors. ${ }^{91}$ The study by Karalok et al showed that patients with recurrent adult granulosa cell tumors who underwent maximal cytoreductive surgery had excellent survival outcomes. ${ }^{92}$ However, the presence of postoperative residual tumor was associated with an increased risk of recurrence not only at initial surgery, but also in the secondary cytoreductive surgery. A retrospective study of 35 patients with recurrent adult granulosa cell tumors by Mangili et al found that among 32 patients who had a complete resection at the time of the initial surgery, 13 patients had relapsed, whereas recurrence occurred in all three patients with residual tumors. ${ }^{93}$ In the same retrospective study, all six patients with residual tumors who underwent secondary cytoreductive surgery had a second recurrence, whereas recurrence occurred in only 11 of 28 patients who underwent complete surgical resection. ${ }^{93}$ Therefore, it is very important to achieve complete resection of tumor in both the initial surgery and secondary cytoreductive surgery.

\section{Chemotherapy}

In addition to surgery for sex cord-stromal tumors, chemotherapy is recommended for patients with advanced disease or recurrence. The most common chemotherapy regimens for sex cord-stromal tumors include bleomycin, etoposide, and cisplatin, cisplatin and etoposide, or carboplatin with paclitaxel. ${ }^{94}$ Although there is no specific guideline for the use of chemotherapy regimens after surgery for recurrent granulosa cell tumors, bleomycin, etoposide, and cisplatin is the preferable chemotherapy regimen for patients with advanced or recurrent tumors. ${ }^{95}$ For patients with recurrent granulosa cell tumors, the National Comprehensive Cancer Network guidelines recommend taxane with or without carboplatin. ${ }^{96}$ Other chemotherapy regimens for recurrent adult granulosa cell tumors include bleomycin, etoposide, and cisplatin, paclitaxel plus platinum based regimens (such as paclitaxel plus cisplatin and paclitaxel plus carboplatin), and paclitaxel plus ifosfamide.$^{97}$

Several studies have shown that postoperative chemotherapy is not associated with improved prognosis and prolonged disease free survival and possibly overall survival of granulosa cell tumor patients. ${ }^{97-99}$ In a study of the impact of adjuvant chemotherapy on disease specific survival in patients with granulosa cell tumors, Oseledchyk et al found that regardless of stage, there were no significant differences in 5 year disease specific survival between patients who received chemotherapy and those who did not. ${ }^{100} \mathrm{~A}$ retrospective study by Wang et al which included 60 patients with stage IC adult granulosa cell tumors (32 in the adjuvant chemotherapy group and 28 in the no adjuvant chemotherapy group), reported that adjuvant chemotherapy in stage IC adult granulosa cell tumors patients was not associated with improved disease free survival. ${ }^{99}$

\section{Hormonal Therapy}

Hormonal therapy is considered another treatment option for patients with tumor recurrence or those with advanced disease. This approach could also be a promising therapeutic approach in the management of granulosa cell tumors, due to the steroidogenic nature of these tumors. Granulosa cell tumors are hormonally active tumors and, as such, generally express steroid hormone receptors. ${ }^{101}$ Hormonal therapy may, therefore, inhibit the proliferation of granulosa cell tumors through several mechanisms. ${ }^{102}$ There is a possibility of classifying these mechanisms as direct effects on the tumor via a local mechanism mediated by specific receptors in the tumor and indirect action on tumors via suppression of gonadotropins or endogenous steroids. ${ }^{102}$ For instance, aromatase inhibitors are a class of hormone therapy drugs used in the management of granulosa cell tumors, which include anastrozole, letrozole, and exemestane ${ }^{29}$ Aromatase inhibitors produce a higher response rate compared with other hormonal therapies used in granulosa cell tumors. ${ }^{29}$

A study by Korach et al which included four patients with recurrent granulosa cell tumors who were treated with an aromatase inhibitor, two treated with letrozole, and two with anastrozole, showed clinical responses with both types of aromatase inhibitors and three of the four patients exhibited complete responses. ${ }^{103}$ A cohort study of adult granulosa cell tumor patients treated with different hormone therapy drugs (aromatase inhibitors, gonadotropin releasing hormone agonists, steroidal progestins, and selective estrogen receptor modulators) by van Meurs et al reported only $18 \%$ objective response rate although the majority of patients $(60 \%)$ had stable disease. ${ }^{104}$ Another possible hormone therapy for granulosa cell tumors is activin A inhibitor. Activin $A$ is a protein that belongs to the transforming growth factor $\beta$ superfamily and is primarily produced by ovarian granulosa cells and pituitary cells. ${ }^{105}$ This protein plays a key role in inducing granulosa cell proliferation during folliculogenesis. ${ }^{105} \mathrm{~A}$ study of 12 patients with granulosa cell tumors treated with activin A inhibitor (STM434) reported that approximately $80 \%$ of patients had dose related metabolic effects and no antitumor response was observed. ${ }^{106}$

Another promising therapeutic approach for recurrent granulosa cell tumors is targeted therapy. One example of this therapy is tyrosine kinase inhibitors, which are potential therapeutic targets that have been used to target specific proteins in different types of solid tumors. ${ }^{107}$ In 2019, a case study of recurrent adult granulosa cell tumorus treated with imatinib monotherapy, which is a tyrosine kinase inhibitor, reported that this targeted drug was well tolerated and resulted in long term stabilization of recurrent tumors where there was no significant increase in the size of the tumor nodules. ${ }^{108}$ In addition to tyrosine kinase inhibitor targeted therapy, inhibitors of apoptosis proteins might be a promising targeted therapeutic for granulosa cell tumors. ${ }^{109} \mathrm{~A}$ study by Bagnjuk et al found that the analogs of the second mitochondria derived activator of caspases SMAC mimetic BV-6, which blocks the inhibitor of apoptosis proteins, is capable of inducing apoptosis in KGN cells (metastatic granulosa cell tumor cell line). ${ }^{109}$ 


\section{Conclusion}

In conclusion, surgery remains the most effective therapeutic approach for the management of both primary and relapsed tumors, while adjuvant chemotherapy may be used only for advanced or unresectable tumors due to the toxicity and limited efficacy of this therapy. Hormonal therapy appears promising for relapsed tumors, but further assessment is needed. There is still an unmet clinical need for the identification of therapeutic targets and the development of targeted therapeutic agents to be added to the management modalities for aggressive and recurrent sex cordstromal tumors, which is a challenging task as these tumors generally seem to have a low gene mutation burden, and particularly in genes commonly involved in tumor development and progression.

Contributors RAH: preparation of the manuscript. IAM: revision of the manuscript. ME-B: concept, design, and revision of the manuscript.

Funding The authors have not declared a specific grant for this research from any funding agency in the public, commercial or not-for-profit sectors.

Competing interests None declared.

Patient consent for publication Not required.

Provenance and peer review Not commissioned; externally peer reviewed.

\section{REFERENCES}

1 Schultz KAP, Harris AK, Schneider DT, et al. Ovarian sex cordstromal tumors. J Oncol Pract 2016;12:940-6.

2 Abu-Rustum NR, Restivo A, Ivy J, et al. Retroperitoneal nodal metastasis in primary and recurrent granulosa cell tumors of the ovary. Gynecol Oncol 2006;103:31-4.

3 Thrall MM, Paley P, Pizer E, et al. Patterns of spread and recurrence of sex cord-stromal tumors of the ovary. Gynecol Oncol 2011;122:242-5.

4 Ray-Coquard I, Brown J, Harter P, et al. Gynecologic Cancer InterGroup (GCIG) consensus review for ovarian sex cord stromal tumors. Int J Gynecol Cancer 2014;24:S42-7.

5 Terzic ILL M, Ladjevic N, Terzic S, et al. The longest period to recurrence of granulosa cell ovarian tumor: 41 years after initial diagnosise. Eur J Gynaecol Oncol 2018;39:800-2.

6 Haroon S, Zia A, Idrees R, et al. Clinicopathological spectrum of ovarian sex cord-stromal tumors; 20 years' retrospective study in a developing country. J Ovarian Res 2013;6:87

7 Horta M, Cunha TM. Sex cord-stromal tumors of the ovary: a comprehensive review and update for radiologists. Diagn Interv Radiol 2015;21:277-86.

8 Yen P, Khong K, Lamba R, et al. Ovarian fibromas and fibrothecomas: sonographic correlation with computed tomography and magnetic resonance imaging: a 5-year single-institution experience. J Ultrasound Med 2013;32:13-18.

9 Numanoglu C, Kuru O, Sakinci M, et al. Ovarian fibroma/ fibrothecoma: retrospective cohort study shows limited value of risk of malignancy index score. Aust N Z J Obstet Gynaecol 2013;53:287-92.

10 Obeidat RA, Aleshawi AJ, Obeidat HA, et al. A rare presentation of ovarian fibrothecoma in a middle age female: case report. Int $J$ Womens Health 2019;11:149-52.

11 Pirschner F, Bastos PM, Contarato GL, et al. Gorlin syndrome and bilateral ovarian fibroma. Int J Surg Case Rep 2012;3:477-80.

12 Fujii K, Miyashita T. Gorlin syndrome (nevoid basal cell carcinoma syndrome): update and literature review. Pediatr Int 2014;56:667-74.

13 Evans DG, Farndon PA. Nevoid basal cell carcinoma syndrome. In: Adam MP, Ardinger HH, Pagon RA, et al, eds. GeneReviews. Seattle (WA): University of Washington, Seattle 1993-2020, University of Washington, Seattle, 2020.

14 Tsuji T, Catasus L, Prat J. Is loss of heterozygosity at 9q22.3 (PTCH gene) and 19p13.3 (STK11 gene) involved in the pathogenesis of ovarian stromal tumors? Hum Pathol 2005;36:792-6.

15 Streblow RC, Dafferner AJ, Nelson M, et al. Imbalances of chromosomes 4, 9, and 12 are recurrent in the thecoma-fibroma group of ovarian stromal tumors. Cancer Genet Cytogenet 2007;178:135-40.
16 Zhang H, Zhang G-F, Wang T-P, et al. Value of 3.0 T diffusionweighted imaging in discriminating thecoma and fibrothecoma from other adnexal solid masses. J Ovarian Res 2013;6:58.

17 Strickland KC, Nucci MR, Lee KR, et al. Sex cord-stromal and miscellaneous tumors of the ovary. In: Crum CP, Nucci MR, Howitt BE, et al, eds. Diagnostic gynecologic and obstetric pathology. 3rd Edition. Philadelphia: Content Repository Only! 2018: 1011-49.

18 Mrózek K, Limon J, Dẹbniak J, et al. Trisomy 12 and 4 in a thecoma of the ovary. Gynecol Oncol 1992;45:66-8.

19 Lee CM, Lim S, Cho HY, et al. Sclerosing stromal tumor of the ovary in postmenopausal women: a report of two cases. $J$ Menopausal Med 2015;21:115-9.

20 Atram M, Sharma S, et al. Sclerosing stromal tumor of the ovary. Obstet Gynecol Sci 2014;57:405-8.

21 Park CK, Kim HS. Clinicopathological characteristics of ovarian sclerosing stromal tumor with an emphasis on TFE3 overexpression. Anticancer Res 2017;37:5441-7.

$22 \mathrm{Kim} \mathrm{SH}$, Da Cruz Paula A, Basili T, et al. Identification of recurrent FHL2-GLI2 oncogenic fusion in sclerosing stromal tumors of the ovary. Nat Commun 2020;11:44

23 Murakami M, Wroblewski J, Kawagoe H. Microcystic stromal tumor resected by laparoscopic surgery. Gynecol Minim Invasive Ther 2017;6:135-8.

24 Lee JH, Kim H-S, Cho NH, et al. Genetic analysis of ovarian microcystic stromal tumor. Obstet Gynecol Sci 2016;59:157-62.

25 Rabban JT, Karnezis AN, Devine WP. Practical roles for molecular diagnostic testing in ovarian adult granulosa cell tumour, SertoliLeydig cell tumour, microcystic stromal tumour and their mimics. Histopathology 2020;76:11-24.

26 Lee SH, Koh YW, Roh HJ, et al. Ovarian microcystic stromal tumor: a novel extracolonic tumor in familial adenomatous polyposis. Genes Chromosomes Cancer 2015;54:353-60.

27 Zhang Y, Tao L, Yin C, et al. Ovarian microcystic stromal tumor with undetermined potential: case study with molecular analysis and literature review. Hum Pathol 2018;78:171-6.

$28 \mathrm{Li} \mathrm{J}$, Bao R, Peng S, et al. The molecular mechanism of ovarian granulosa cell tumors. J Ovarian Res 2018;11:13.

29 Yang AD, Curtin J, Muggia F. Ovarian adult-type granulosa cell tumor: focusing on endocrine-based therapies. Int J Endocr Oncol 2018;5:IJE08.

30 Kanthan R, Senger J-L, Kanthan S. The multifaceted granulosa cell tumours-myths and realities: a review. ISRN Obstet Gynecol, 2012: 878635.

31 Jamieson S, Fuller PJ. Molecular pathogenesis of granulosa cell tumors of the ovary. Endocr Rev 2012;33:109-44.

32 Hafez ESE. Male and female inhibin. Arch Androl 1980;5:131-58.

33 Mylonas I, Worbs S, Shabani N, et al. Inhibin-alpha subunit is an independent prognostic parameter in human endometrial carcinomas: analysis of inhibin/activin-alpha, -betaA and -betaB subunits in 302 cases. Eur J Cancer 2009;45:1304-14.

34 Kaneko H. Subchapter 33A - inhibin. In: Takei Y, Ando H, Tsutsui K, eds. Handbook of hormones. San Diego: Academic Press, 2016: 292.

35 Kottarathil VD, Antony MA, Nair IR, et al. Recent advances in granulosa cell tumor ovary: a review. Indian J Surg Oncol 2013;4:37-47.

36 Lappöhn RE, Burger HG, Bouma J, et al. Inhibin as a marker for granulosa-cell tumors. N Engl J Med 1989;321:790-3.

37 Petraglia F, Luisi S, Pautier P, et al. Inhibin B is the major form of inhibin/activin family secreted by granulosa cell tumors. J Clin Endocrinol Metab 1998;83:1029-32.

38 Mom CH, Engelen MJA, Willemse PHB, et al. Granulosa cell tumors of the ovary: the clinical value of serum inhibin $A$ and $B$ levels in a large single center cohort. Gynecol Oncol 2007;105:365-72.

39 Koukourakis GV, Kouloulias VE, Koukourakis MJ, et al. Granulosa cell tumor of the ovary: tumor review. Integr Cancer Ther 2008;7:204-15.

40 François CM, Wargnier R, Petit F, et al. 17ß-estradiol inhibits spreading of metastatic cells from granulosa cell tumors through a non-genomic mechanism involving GPER1. Carcinogenesis 2015;36:564-73.

41 Gustafson ML, Lee MM, Scully RE, et al. Müllerian inhibiting substance as a marker for ovarian sex-cord tumor. N Engl J Med 1992;326:466-71.

42 Kim JH, MacLaughlin DT, Donahoe PK. Müllerian inhibiting substance/anti-Müllerian hormone: a novel treatment for gynecologic tumors. Obstet Gynecol Sci 2014;57:343-57.

43 Zec I, Tislaric-Medenjak D, Megla ZB, et al. Anti-Müllerian hormone: a unique biochemical marker of gonadal development and fertility in humans. Biochem Med 2011;21:219-30. 
44 Anckaert E, Öktem M, Thies A, et al. Multicenter analytical performance evaluation of a fully automated anti-Müllerian hormone assay and reference interval determination. Clin Biochem 2016:49:260-7.

45 Teixeira J, Maheswaran S, Donahoe PK. Müllerian inhibiting substance: an instructive developmental hormone with diagnostic and possible therapeutic applications. Endocr Rev 2001;22:657-74.

46 Khosla D, Dimri K, Pandey A, et al. Ovarian granulosa cell tumor: clinical features, treatment, outcome, and prognostic factors. N Am J Med Sci 2014;6:133-8.

47 Jamieson S, Fuller PJ. Management of granulosa cell tumour of the ovary. Curr Opin Oncol 2008;20:560-4.

48 Phyoe-Battaglia T, Bartels C, Nulsen J, et al. In vitro fertilization with granulosa cell tumor: a report of two cases. J Assist Reprod Genet 2018;35:1919-21.

49 Babarović E, Franin I, Klarić M, et al. Adult granulosa cell tumors of the ovary: a retrospective study of 36 FIGO stage I cases with emphasis on prognostic pathohistological features. Anal Cell Pathol 2018.

50 Tak JY, Chong GO, Park JY, et al. Adult granulosa cell tumor presenting with massive ascites, elevated CA-125 level, and low ${ }^{18}$ F-fluorodeoxyglucose uptake on positron emission tomography/ computed tomography. Obstet Gynecol Sci 2015;58:423-6.

51 Takahashi A, Kimura F, Yamanaka A, et al. The FOXL2 mutation (c.402 $\mathrm{C}^{\wedge} \mathrm{gt} ; \mathrm{G}$ ) in adult-type ovarian granulosa cell tumors of three Japanese patients: clinical report and review of the literature. Tohoku J Exp Med 2013;231:243-50.

52 Schrader KA, Gorbatcheva B, Senz J, et al. The specificity of the FOXL2 c.402C>G somatic mutation: a survey of solid tumors. PLoS One 2009;4:e7988.

53 Färkkilä A, McConechy MK, Yang W, et al. FOXL2 402C>G mutation can be identified in the circulating tumor DNA of patients with adult-type granulosa cell tumor. J Mol Diagn 2017;19:126-36.

54 Yanagida S, Anglesio MS, Nazeran TM, et al. Clinical and genetic analysis of recurrent adult-type granulosa cell tumor of the ovary: persistent preservation of heterozygous c.402C>G FOXL2 mutation. PLoS One 2017;12:e0178989.

$55 \mathrm{Li}$ J, Bao R, Peng S, et al. The molecular mechanism of ovarian granulosa cell tumors. J Ovarian Res 2018;11:13

56 Fuller PJ, Leung D, Chu S. Genetics and genomics of ovarian sex cord-stromal tumors. Clin Genet 2017;91:285-91.

57 Anttonen M, Pihlajoki M, Andersson N, et al. Foxl2, GATA4, and Smad3 co-operatively modulate gene expression, cell viability and apoptosis in ovarian granulosa cell tumor cells. PLoS One 2014;9:e85545

58 D'Angelo E, Mozos A, Nakayama D, et al. Prognostic significance of FOXL2 mutation and mRNA expression in adult and juvenile granulosa cell tumors of the ovary. Mod Pathol 2011;24:1360-7.

59 Alexiadis M, Rowley SM, Chu S, et al. Mutational landscape of ovarian adult granulosa cell tumors from whole exome and targeted TERT promoter sequencing. Mol Cancer Res 2019;17:177-85.

60 Berghe Vden I, Dal Cin P, De Groef K, et al. Monosomy 22 and trisomy 14 may be early events in the tumorigenesis of adult granulosa cell tumor. Cancer Genet Cytogenet 1999;112:46-8.

61 Caburet S, Anttonen M, Todeschini A-L, et al. Combined comparative genomic hybridization and transcriptomic analyses of ovarian granulosa cell tumors point to novel candidate driver genes. BMC Cancer 2015;15:251.

62 Alexiadis M, Chu S, Leung D, et al. Transcriptomic analysis of stage 1 versus advanced adult granulosa cell tumors. Oncotarget 2016;7:14207-19.

63 Kraus F, Dremaux J, Altakfi W, et al. FOXL2 homozygous genotype and chromosome instability are associated with recurrence in adult granulosa cell tumors of the ovary. Oncotarget 2020;11:419-28.

64 Wang W-C, Lai Y-C. Molecular pathogenesis in granulosa cel tumor is not only due to somatic FOXL2 mutation. J Ovarian Res 2014;7:88

$65 \mathrm{Xu} \mathrm{Y,} \mathrm{Li} \mathrm{X,} \mathrm{Wang} \mathrm{H,} \mathrm{et} \mathrm{al.} \mathrm{Hypermethylation} \mathrm{of} \mathrm{CDH13,} \mathrm{DKK3} \mathrm{and}$ FOXL2 promoters and the expression of EZH2 in ovary granulosa cell tumors. Mol Med Rep 2016:14:2739-45

66 Dhillon VS, Shahid M, Husain S. Cpg methylation of the FHIT, FANCF, cyclin-D2, BRCA2 and RUNX3 genes in granulosa cell tumors (GCTs) of ovarian origin. Mol Cancer 2004;3:33

67 Dhillon VS, Young AR, Husain SA, et al. Promoter hypermethylation of MGMT, CDH1, RAR- $\beta$ and Syk tumour suppressor genes in granulosa cell tumours (GCTs) of ovarian origin. Br J Cancer 2004;90:874-81.

68 Ashnagar A, Alavi S, Nilipour Y, et al. Massive ascites as the only sign of ovarian juvenile granulosa cell tumor in an adolescent: a case report and a review of the literature. Case Rep Oncol Med 2013.
69 Sivasankaran S, Itam P, Ayensu-Coker L, et al. Juvenile granulosa cell ovarian tumor: a case report and review of literature. J Pediatr Adolesc Gynecol 2009;22:e114-7.

70 Inada Y, Nakai G, Yamamoto K, et al. Rapidly growing juvenile granulosa cell tumor of the ovary arising in adult: a case report and review of the literature. J Ovarian Res 2018;11:100

71 Dogra S, Yadav YK, Sharma U, et al. Juvenile granulosa cell tumor with an unusual immunoprofile, presenting as precocious puberty. South Asian J Cancer 2013:2:150

72 Kobel M, Gilks CB, Huntsman DG. Adult-type granulosa cell tumors and FOXL2 mutation. Cancer Res 2009;69:9160-2.

73 Kim S-Y. Insights into granulosa cell tumors using spontaneous or genetically engineered mouse models. Clin Exp Reprod Med 2016;43:1-8.

74 Kalfa N, Ecochard A, Patte C, et al. Activating mutations of the stimulatory $\mathrm{G}$ protein in juvenile ovarian granulosa cell tumors: a new prognostic factor? J Clin Endocrinol Metab 2006:91:1842-7.

75 Bessière L, Todeschini A-L, Auguste A, et al. A hot-spot of in-frame duplications activates the oncoprotein Akt1 in juvenile granulosa cell tumors. EBioMedicine 2015;2:421-31.

76 Zizi-Sermpetzoglou A, Petrakopoulou N, Tepelenis N, et al. Pure Sertoli cell tumor. A case report and review of the literature. Eur J Gynaecol Oncol 2010;31:117-9.

77 Pejovic T, Heim S, Alm P, et al. Isochromosome 1q as the sole karyotypic abnormality in a Sertoli cell tumor of the ovary. Cancer Genet Cytogenet 1993;65:79-80.

78 Young $\mathrm{RH}$. Sex cord-stromal tumors of the ovary and testis: their similarities and differences with consideration of selected problems. Mod Pathol 2005;18:S81-98.

79 Meur NL, Martin C, Saugier-Veber P, et al. Complete germline deletion of the STK11 gene in a family with Peutz-Jeghers syndrome. Eur J Hum Genet 2004;12:415-8.

80 Tomlinson IP, Houlston RS. Peutz-Jeghers syndrome. J Med Genet 1997;34:1007-11

81 Qian Q, You Y, Yang J, et al. Management and prognosis of patients with ovarian sex cord tumor with annular tubules: a retrospective study. BMC Cancer 2015;15:270

82 Connolly DC, Katabuchi H, Cliby WA, et al. Somatic mutations in the STK11/LKB1 gene are uncommon in rare gynecological tumor types associated with Peutz-Jegher's syndrome. Am J Pathol 2000;156:339-45.

83 Nosov V, Park S, Rao J, et al. Non-Peutz-Jeghers syndrome associated ovarian sex cord tumor with annular tubules: a case report. Fertil Steril 2009;92:1497.e5-1497.e8.

84 Tandon R, Goel P, Saha PK, et al. A rare ovarian tumor - SertoliLeydig cell tumor with heterologous element. MedGenMed 2007;9:44.

85 Cai S-Q, Zhao S-H, Qiang J-W, et al. Ovarian Sertoli-Leydig cell tumors: MRI findings and pathological correlation. J Ovarian Res 2013;6:73.

86 Abu-Zaid A, Azzam A, Alghuneim LA, et al. Poorly differentiated ovarian Sertoli-Leydig cell tumor in a 16-year-old single woman: a case report and literature review. Case Rep Obstet Gynecol 2013.

87 Osakabe M, Sato C, Suzuki M, et al. Mesenteric extraovarian Sertoli-Leydig cell tumor without DICER1 hotspot mutation: a case report. Diagn Pathol 2019;14:27.

88 Manegold E, Tietze L, Günther K, et al. Trisomy 8 as sole karyotypic aberration in an ovarian metastasizing Sertoli-Leydig cell tumor. Hum Pathol 2001;32:559-62.

89 Verdorfer I, Horst D, Höllrigl A, et al. Sertoli-Leydig cell tumours of the ovary and testis: a CGH and fish study. Virchows Arch 2007;450:267-71

90 Chen Y-C, Chang L-C, Soong R-S. A late recurring and easily forgotten tumor: ovarian granulosa cell tumor. World J Surg Oncol 2012;10:85.

91 Namaky D, Ramirez P, Munsell M, et al. Secondary cytoreductive surgery: a key tool in the management of recurrent ovarian sex cord-stromal tumors. Gynecol Oncol 2011;120:S40.

92 Karalok A, Ureyen I, Tasci T, et al. Maximum surgical effort is warranted for recurrent adult granulosa cell tumors of ovary. Tumori J 2016;102:404-8.

93 Mangili G, Sigismondi C, Frigerio L, et al. Recurrent granulosa cell tumors (GCTs) of the ovary: a MITO-9 retrospective study. Gynecol Oncol 2013;130:38-42.

94 Ray-Coquard I, Morice P, Lorusso D, et al. Non-epithelial ovarian cancer: ESMO clinical practice guidelines for diagnosis, treatment and follow-up. Ann Oncol 2018;29:iv1-18.

95 Pectasides D, Pectasides E, Psyrri A. Granulosa cell tumor of the ovary. Cancer Treat Rev 2008;34:1-12. 


\section{Review}

96 Nakai H, Koike E, Murakami K, et al. Clinical determinants affecting indications for surgery and chemotherapy in recurrent ovarian granulosa cell tumor. Health Care 2019;7:145.

97 Zhao D, Zhang Y, Ou Z, et al. Characteristics and treatment results of recurrence in adult-type granulosa cell tumor of ovary. $J$ Ovarian Res 2020;13:19.

98 Meisel JL, Hyman DM, Jotwani A, et al. The role of systemic chemotherapy in the management of granulosa cell tumors. Gynecol Oncol 2015;136:505-11.

99 Wang D, Xiang Y, Wu M, et al. Is adjuvant chemotherapy beneficial for patients with FIGO stage IC adult granulosa cell tumor of the ovary? J Ovarian Res 2018;11.

100 Oseledchyk A, Gennarelli RL, Leitao MM, et al. Adjuvant chemotherapy in patients with operable granulosa cell tumors of the ovary: a surveillance, epidemiology, and end results cohort study. Cancer Med 2018;7:2280-7.

101 Bufa A, Farkas N, Preisz Z, et al. Diagnostic relevance of urinary steroid profiles on ovarian granulosa cell tumors: two case reports. J Med Case Rep 2017;11:166

102 Kim HJ, Lee S-C, Bae SB, et al. Gnrh agonist therapy in a patient with recurrent ovarian granulosa cell tumors. J Korean Med Sci 2009;24:535-8.
103 Korach J, Perri T, Beiner M, et al. Promising effect of aromatase inhibitors on recurrent granulosa cell tumors. Int J Gynecol Cancer 2009;19:830-3.

104 van Meurs HS, van der Velden J, Buist MR, et al. Evaluation of response to hormone therapy in patients with measurable adult granulosa cell tumors of the ovary. Acta Obstet Gynecol Scand 2015;94:1269-75.

105 Bonilla L, Oza AM. Targeting TGF $\beta$ pathway in adult granulosa cell tumor: opening Pandora's box? Clin Cancer Res 2019;25:5432-4.

106 Tao JJ, Cangemi NA, Makker V, et al. First-in-human phase I study of the activin A inhibitor, STM 434, in patients with granulosa cell ovarian cancer and other advanced solid tumors. Clin Cancer Res 2019;25:5458-65.

107 Vergoulidou M. More than a decade of tyrosine kinase inhibitors in the treatment of solid tumors: what we have learned and what the future holds. Biomark Insights 2015;10s3:BMI.S22436-40.

108 Poddubskaya EV, Baranova MP, Allina DO, et al. Personalized prescription of imatinib in recurrent granulosa cell tumor of the ovary: case report. Cold Spring Harb Mol Case Stud 2019;5:a003434.

109 Bagnjuk K, Kast VJ, Tiefenbacher A, et al. Inhibitor of apoptosis proteins are potential targets for treatment of granulosa cell tumors - implications from studies in KGN. J Ovarian Res 2019;12:76. 